\title{
$\mathrm{u}$-Health 시스템을 위한 음성신호 분석 기반의 간 기능 모니터링에 관한 연구
}

\author{
김 봉 현 $^{+}$조 동 욱 $^{++}$
}

요 약

\begin{abstract}
현대 사회에서 식습관의 변화, 스트레스, 음주 등으로 인해 다양한 간 질환이 발생되거나 악화되어 가고 있다. 따라서 본 논문에서는 간 질 환이 음성에 미치는 영향을 연구하여 간 질환을 조기에 진단할 수 있는 방법론을 제안하였다. 이를 위해 간 질환자를 대상으로 입원했을 때와 치료로 인해 정상적으로 퇴원했을 때의 음성을 각각 수집하여 음성 분석 요소를 적용한 실험을 수행하였다. 특히, 한의학적으로 간(肝)과 관련 있는 발음인 아음(牙音)에 대한 분석 실험으로 제 3 포먼트 주파수 대역폭과 발음 요소값을 적용한 실험을 수행하였으며 이를 통해 간 질환이 공 명강과 발성에 미치는 영향을 객관적 지표로 출력하는 연구를 행하였다. 또한 실험 결과를 기반으로 $\mathrm{u}-\mathrm{Health}$ 환경에서 간 기능을 모니터링하 는 시스템 설계에 관한 연구를 수행하였다.
\end{abstract}

키워드 : 3 포먼트 주파수, Voice Breaks, 발화속도, 음성분석, 간 기능

\section{A Study on Monitoring of Liver Function Based on Voice Signal Analysis for $\mathrm{u}$-Health System}

\author{
Bong Hyun $\mathrm{Kim}^{\dagger} \cdot$ Dong UK $\mathrm{Cho}^{++}$
}

\begin{abstract}
There is getting worse to various liver diseases due to change in eating habits, stress, alcohol etc in modern society. Therefore, we proposed methodology to diagnose early for liver disease to study the influence on voice in liver diseases. To this end, we carried out experiment to apply parameter of voice analysis to collect each voice inpatients and patients by treatment of liver diseases patients. Particularly, we carried out experiment to apply element value of pronunciation and the third formant frequency bandwidths about velar sounds associated liver in oriental medicine, then to produce objective index resonance cavity and influence vocalization in liver diseases. In addition, we carried out to study about design of system to monitoring a liver function in u-Health environment based on result by experiment.
\end{abstract}

Keywords : 3 Formant Frequency, Voice Breaks, Voice Speed, Voice Analysis, Liver Function

\section{1. 서 론}

현대 사회는 국민 생활 경제의 향상으로 인해 식습관이나 생활습관, 생활형태 등의 변화로 비만자가 급증하고 있는 추세이며 특히, 스트레스와 음주로 인해 다양한 간질환이 발생되거나 악화되고 있는 실정이다. 이와 같은 사회적 흐 름의 변화로 인해 간질환의 유병률이 증가할 것으로 예상되 고 있다[1]. 우리나라의 경우는 30 50대에서 암으로 인한

† 정 회 원: 충북도립대학교 전자정보계열 외래강사

†† 정 회 원 : 충북도립대학교 전자정보계열 교수(교신저자) 논문접수: 2011년 10월 10일

수 정 일: 1 차 2011년 11월 22일

심사완료 : 2011년 11월 25일
사망을 제외하고는 간질환이 1 3위를 차지하고 있으며 암 으로 인한 사망률에서도 위암, 폐암과 더불어 간암이 빈도 의 차이가 거의 없는 3 대 암으로 자리잡고 있다[2].

간(肝)은 동양의학적 이론으로 볼 때 다른 인체 장기와는 좀 다르게 심장과 함께 인체의 주 기관으로 표현되며 혈을 만들고 공급해 주는 기관으로 간과 심장에 발병한 질환은 동시에 치료가 어려운 특별한 인체 장기로 분류된다. 즉, 간 은 혈을 생성하고 심장은 생성된 혈을 온몸 구석구석에 공 급해 주는 역할을 수행한다. 간은 초기에 염증이 생기면 치 료를 받지만 조기에 진단하지 못하고 오랜 기간동안 염증을 방치하게 되면 간이 상하고 손상 부위를 도려내지 못할 정 도로 커지게 되면 이식을 받아야 하며 이러한 절차를 무시 할 경우엔 죽음까지 초래하게 된다[3][4]. 간은 다양하고 중 

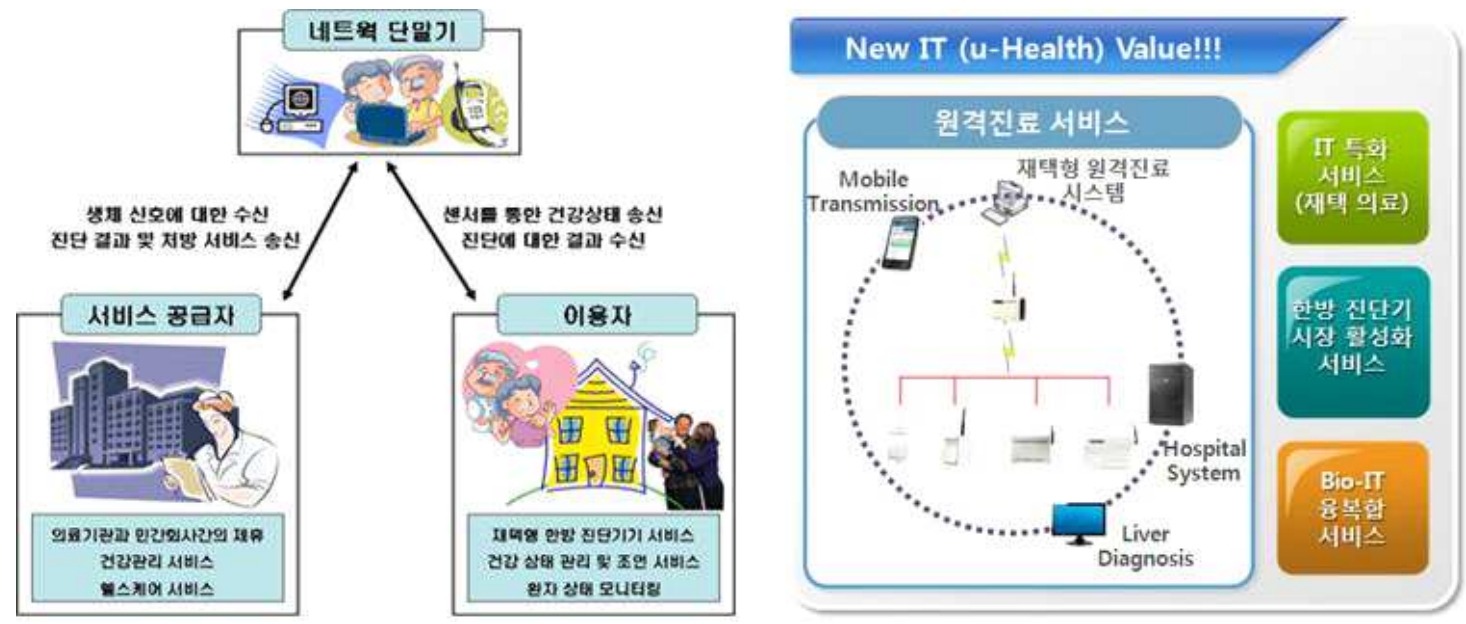

(그림 1) 최종 모니터링 시스템 설계도

요한 기능들을 수행하기 때문에 간 기능이 심하게 저하되면 여러 가지 문제가 발생하여 각종 질환에 발병하게 된다 [5][6]. 간 질환은 만성간염에서 간경변증에 이르기까지 종류 와 심한 정도가 다양하고 증상도 전혀 없는 경우에서부터 심한 경우에 이르기까지 다양하다[7]. 현대 의료 분야는 질 병의 진단과 치료뿐만 아니라 질병의 예방 및 건강증진을 위한 관리, 유지의 역할도 중요하게 대두되고 있다. 즉, 질병 의 조기 발견과 진단으로 예방 및 관리를 생활화하고 건강 수준을 높이는 방향을 제시하는 등 건강증진을 유도하는 계 기를 증대시키고 있다. 또한, IT의 네트워크화, 지능화, 내재 화의 특성을 통해 기존 기술 및 산업간 융합의 원천기술화 시키는 IT 융합 산업이 경쟁력 우위 확보 및 신성장 동력화 로 추진되면서 IT 산업과 타 산업간의 융복합화가 급속히 촉진되고 있다. 특히, 의료 분야는 3 대 분야별 17 개 신성장 동력 중 IT 의료융합 산업 비전 및 신성장 동력을 위한 Top Brand를 도출하는 추세이며 IT를 융합하여 의료산업에 고부가가치의 신산업을 창출할 수 있는 연구 방향을 설정하 여 의료 IT 인프라 구축을 위한 통합형 로드맵이 수립된 상 황이다. 이와 같은 시대적 흐름을 반영하듯 의료 분야의 $\mathrm{New}$ IT 기술이 지속적으로 연구되고 있으며 특정 인체 장 기 분야에 대한 모니터링 시스템을 설계, 개발하여 재택형 원격진료 서비스를 수행하기 위한 연구가 진행되고 있다.

따라서 본 논문에서는 IT 의료 분야의 융복합적 기반 기 술을 개발하기 위한 연구로 간질환이 음성 분석학적 요소에 미치는 영향을 연구하여 음성을 통한 조기 진단이 가능한 객관적 출력 변수를 설계하기 위한 실험을 수행하였다. 이 를 위해 간 질환을 않고 있는 환자를 대상으로 피실험자 집 단으로 구성하여 간질환으로 인해 입원했을 때와 치료 후 정상적인 간 기능을 검진받고 퇴원했을 때의 음성을 각각 수집하였다. 수집된 입력 음성을 기반으로 간(肝)과 관련있 는 발음인 아음(牙音)을 중점으로 단계별 포먼트 주파수 대 역폭을 적용한 실험을 1 차적으로 수행하여 실험 결과의 유 의성이 도출되는 포먼트 주파수 대역폭을 추출하였다. 또한, 간이 어떤 음성 분석 요소와 관련이 있는지를 추출하기 위
해 적용 가능한 모든 음성 분석 요소를 가지고 실험을 수행 하여 유의성이 도출되는 음성 분석 요소에 대해 실험 결과 를 분석하고 최종적으로 간 질환으로 인해 공명강과 발성에 미치는 영향을 분석하는 연구를 수행하였다.

\section{2. 연구 과정 및 방법}

\section{1 연구 과정}

본 논문에서는 생체 신호 중에서 개인적 특징을 반영하고 있으며 쉽게 변하지 않는 음성에 대한 분석을 통해 언어학 적 요소와의 연계성을 기반으로 음성분석 요소의 적용에 대 한 결과를 도출하여 간과의 상관성을 분석하였다. 즉, 간 질 환자를 대상으로 간 질환으로 인해 입원했을 때와 치료 후

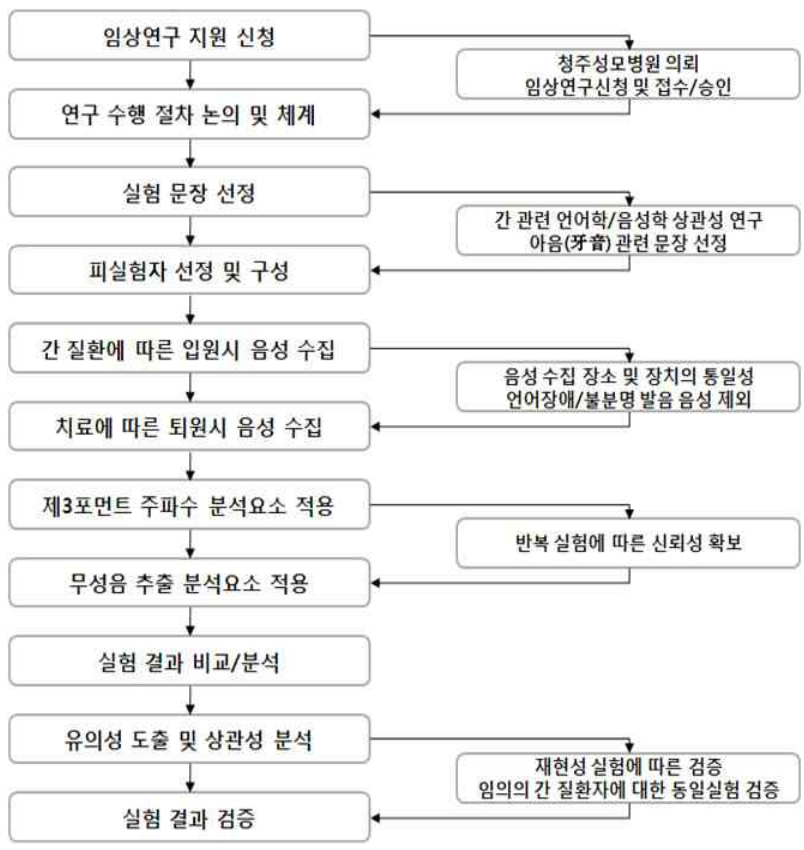

(그림 2) 연구 과정 흐름도 
에 퇴원했을 때의 음성을 각각 수집하고 음성 분석 요소를 적용하여 간 질환으로 인해 공명강과 발성에 미치는 영향을 분석하는 연구를 수행하였다.

본 논문에서 실험에 사용할 임상 자료는 청주성모병원에 서 임상연구 지원 및 수행에 관한 승인 절차를 얻어 수집하 였으며 간 질환 전문의의 검토와 승인 과정을 거쳐 실험에 필요한 간 질환을 않고 있는 피실험자 집단을 남성 25명과 여성 15명으로 구성하였다. 또한, 음성 자료는 간 질환으로 인한 입원과 치료에 의한 퇴원시의 음성을 각각 수집하였다.

실험에 사용한 문장은 한의학적 진단 이론에 근거하여 간 질환자의 음성 중에서 아음에 해당하는 “ㄱ, ㄱา" 발음이 불 분명할 것이라는 가설을 전제조건으로 연구를 진행하였다. 이를 위해 연구에 필요한 실험 대상자들을 간 질환자로 선 정하여 동일한 조건과 형태로 치료 전과 후의 음성을 녹음 하여 비교, 분석을 행하였다. 동일 실험에 대한 환경은 잡음 이 없는 공간에서 실험 대상자의 입과 마이크를 $15 \mathrm{~cm}$ 로 유 지한 후 아음에 해당하는 “ㄱ, 77 " 발음이 많이 포함된 “가 까이 사는 가까끼는 코끼리와 같다."를 10 초 이내에 평상시 음성으로 3 회 이상 반복적으로 녹음하여 분석하였다. 아래 $<$ 표 1>과<표 2>는 실험 대상자로 선정된 남, 여 피실험자 집단의 구성표를 나타낸 것이다.

〈표 1〉 남성 피실험자 집단 구성표

\begin{tabular}{c|c}
\hline 구분 & 병명 \\
\hline LM-01 & 간경변 \\
\hline LM-02 & 간경변 \\
\hline LM-03 & 간경변 \\
\hline LM-04 & B형 간염 바이러스 \\
\hline LM-05 & B형 간염 바이러스에 의한 간경변 \\
\hline LM-06 & B형 간염 바이러스에 의한 간경변 \\
\hline LM-07 & 알코올에 의한 간경변 \\
\hline LM-08 & A형 간염 \\
\hline LM-09 & A형 간염 \\
\hline LM-10 & 독성 간염 \\
\hline LM-11 & 알코올에 의한 간경변 \\
\hline LM-12 & 알코올에 의한 간경변 \\
\hline LM-13 & 독성 간염 \\
\hline LM-14 & 간경변 \\
\hline LM-15 & B형 간염 바이러스 \\
\hline LM-16 & B형 간염 바이러스에 의한 간경변 \\
\hline LM-17 & 독성 간염 \\
\hline LM-18 & 알코올에 의한 간경변 \\
\hline LM-19 & 간경변 \\
\hline LM-20 & 간경변 \\
\hline LM-21 경 간염 \\
\hline LM-22 형 간염 \\
\hline LM-23 밤이러스 \\
\hline LM-25 & B형 간염 바이러스에 안 간경변 \\
\hline
\end{tabular}

〈표 2〉여성 피실험자 집단 구성표

\begin{tabular}{c|c}
\hline 구분 & 병명 \\
\hline $\mathrm{LF}-01$ & 독성 간염 \\
\hline $\mathrm{LF}-02$ & A형 간염 \\
\hline $\mathrm{LF}-03$ & 급성 $\mathrm{A}$ 형 간염 \\
\hline $\mathrm{LF}-04$ & 급성 $\mathrm{A}$ 형 간염 \\
\hline $\mathrm{LF}-05$ & 급성 $\mathrm{A}$ 형 간염 \\
\hline $\mathrm{LF}-06$ & A형 간염 \\
\hline $\mathrm{LF}-07$ & 급성 $\mathrm{A}$ 형 간염 \\
\hline $\mathrm{LF}-08$ & A형 간염 \\
\hline $\mathrm{LF}-09$ & 급성 $\mathrm{A}$ 형 간염 \\
\hline $\mathrm{LF}-10$ & 독성 간염 \\
\hline $\mathrm{LF}-11$ & 급성 $\mathrm{A}$ 형 간염 \\
\hline $\mathrm{LF}-12$ & 독성 간염 \\
\hline $\mathrm{LF}-13$ & A형 간염 \\
\hline $\mathrm{LF}-14$ & $\mathrm{~A}$ 형 간염 \\
\hline $\mathrm{LF}-15$ & 급성 $\mathrm{A}$ 형 간염 \\
\hline
\end{tabular}

\section{2 연구 방법}

본 논문에서는 음성의 특징 요소에 따라 분석 결과의 차 이가 나타날 수 있다는 이론적 배경을 기반으로 간과 음성 과의 상관성 연구를 공명강과 발성의 변화 측정 실험으로 수행하였다. 이를 위해 한의학적 간의 소리 패턴을 통해 간 과 아음이 연관되어 있다는 것을 기반으로 엄쏘리가 음성학 적 특징 분석 요소 중에서 제 3 포먼트와 관련되어 있다는 것 을 실험하였으며 발성 구간에서의 Number of Voice Breaks 를 추출하여 최종적으로 간 질환이 공명강과 발성에 미치는 영향을 분석하는 연구를 수행하였다. 본 논문에서 연구 방 법으로 적용한 한의학적 진단 이론 배경은 오장(五臟)과 오 음(五音), 그리고 오성(五聲)과의 관계에 의한 청진(㯖診) 이 론이다[8][9].

즉, 한의학에서 간의 소리는 발음상 아음(牙音), 즉 엄쏘 리에 해당한다. 따라서 간에 이상 현상이 발생하면 아음(牙

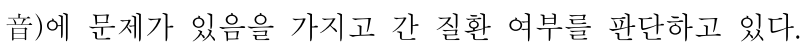
본 논문에서는 한의학에서 간은 엄쏘리와 연계되어 있어 간 에 이상이 있을 때엔 엄쏘리가 불분명함에 초점을 두어 음 성 분석을 수행하였다. 이와 같이 오장(五臟)과 관련된 소리 를 아래<표 3>에 음령오행표로 나타내었다. <표 3>에서 알 수 있듯이 간은 오음(五音)중에서 각(角)소리에 해당하며 발음으로는 엄쏘리 즉, 아음(牙音)임을 알 수 있다[10].

이와 같은 이론을 적용한 연구 방법을 통해 본 논문에서 는 음성 분석 및 음성 변형 프로그램인 프라트(Praat)를 사 용하여 간 질환자의 치료 전과 후의 음성을 입력받아 포먼 트 분석과 Number of Voice Breaks 및 발화 속도 분석을 수행하였다.

먼저, 성도의 변화인 포먼트 주파수 대역폭을 자동으로 추출하기 위해 해당 음성 구간에서 지정한 수의 포먼트를 추출하고 각 포먼트의 위치에 대한 기본값을 생성하는 방식 
〈표 3〉음령오행(晋靈五行)표

\begin{tabular}{|c|c|c|c|c|c|}
\hline $\begin{array}{c}\text { 오행 } \\
\text { (五行) }\end{array}$ & 목(木) & 화(火) & 토(土) & 금(金) & 수(水) \\
\hline $\begin{array}{c}\text { 오장 } \\
\text { (五藏) }\end{array}$ & 간 & 심 & 비 & 폐 & 신 \\
\hline 소리음 & 1,2 획 & 3,4 획 & 5,6획 & 7,8획 & 9,10획 \\
\hline 소리 & $\neg, \neg$ & ᄂ, ᄃ, ᄅ, E & $0, \overline{0}$ & 人, ᄌ, 츠 & ㅁ, ㅂ, 프 \\
\hline 발음 & $\begin{array}{l}\text { 아음 } \\
\text { (牙音) }\end{array}$ & $\begin{array}{l}\text { 설음 } \\
\text { (舌音) }\end{array}$ & $\begin{array}{l}\text { 후음 } \\
\text { (喉音) }\end{array}$ & $\begin{array}{l}\text { 치음 } \\
\text { (齒音) }\end{array}$ & $\begin{array}{c}\text { 순음 } \\
\text { (脣音) }\end{array}$ \\
\hline $\begin{array}{c}\text { 오음 } \\
\text { (五音) }\end{array}$ & 각(角) & 치(緻) & 궁(宮) & 상(商) & 우(牙) \\
\hline
\end{tabular}

으로 제 3 포먼트 주파수 대역폭을 측정하였다. 포먼트 측정 파라메타는 Time step을 분석 창 길이의 $25 \%$ 에 해당하는 시간으로 설정하였으며 Max. number of formants는 최대 가능한 포먼트 개수를 지정하는 것으로 제 4 포먼트까지를 설정하였다. 또한 Maximum formant도 포먼트 개수마다 평 균 $1,000 \mathrm{~Hz}$ 를 기본으로 사용하기 때문에 Max. number of formants를 4 로 지정한 것과 동일하게 $4,000 \mathrm{~Hz}$ 로 지정하였 으며 Window length는 분석할 음성 구간을 지정하는 것으 로 가우시안 방식을 설정하였다. 마지막으로 Pre-emphasis 는 고주파로 갈수록 실제 음성의 진폭이 낮기 때문에 이를 강조하여 선명한 포먼트 값을 추출하기 위한 고역강조필터 를 말하는 것으로 $50 \mathrm{~Hz}$ 를 사용하면 강제적인 증폭없이 기 본 음성에 대한 포먼트 값을 가장 선명하게 추출할 수 있으 며 $100 \mathrm{~Hz}$ 를 사용하면 $6 \mathrm{~dB}$ 의 증폭이 이루어지고 $200 \mathrm{~Hz}$ 를 사용하면 $12 \mathrm{~dB}$ 의 증폭이 이루어진다. Pre-emphasis 각 분 석 창에서 프라트는 가우시안 같은 창을 적용하고 Burg에 의한 알고리즘과 함께 $\mathrm{LPC}$ 계수를 산정한다. 따라서 실험에 서는 포먼트 추출에 대한 왜곡을 배제하고 가장 선명한 결 과 파형을 추출하기 위해 Pre-emphasis를 $50 \mathrm{~Hz}$ 로 지정하여 포먼트 주파수를 추출하였다[11][12].

포먼트 주파수는 LPC 값을 이용해서 구하는 방법으로 역 필터 $\mathrm{A}(\mathrm{z})$ 의 근을 계산하여 포먼트 주파수와 대역폭의 모든 후보를 추출할 수 있으며 어떤 복소근 $Z$ 에 대한 대역폭 $\hat{B}$

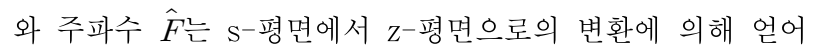
진다.

$$
z=e^{s T}
$$

$s=-\pi \hat{B} \pm j 2 \pi \hat{F}$ 이고 $z=R_{e}(z) \pm j I_{m}(z)$ 는 복소근의 실수부 와 허수부로 정의된다. 그러면 포먼트는 (식 2)와 같이 구할 수 있으며 대역폭은 (식 3)과 같이 구할 수 있다.

$$
\hat{F}=\left(\frac{f_{s}}{2 \pi}\right) \tan ^{-1}\left[\frac{I_{m}(z)}{R_{e}(z)}\right]
$$

$$
\widehat{B}=-\left(\frac{f_{s}}{\pi}\right) \ln |z|
$$

또한, Number of Voice Breaks는 전체 실험 문장을 낭독 하는 과정에서 발생하는 음성의 쉼과 같은 것으로 음성파형 을 펄스파형으로 변환했을 때 표현되지 않는 펄스파형의 구 간을 수치로 추출한 것이다. 즉, 피치 범위의 최소값을 $75 \mathrm{~Hz}$ 로 설정하고 $75 \mathrm{~Hz}$ 로 나누어 모든 펄스 간격을 분석하여 16.6667 밀리초 이상의 펄스 사이 거리가 발생하면 Voice Breaks으로 간주하고 이에 해당하는 Number of Voice Breaks를 추출하였다.

마지막으로 발화속도는 실험 문장을 낭독하는데 소요된 시간을 측정한 것으로 피실험자 집단의 특성 변수로서 출력 지표를 설계하기 위해 측정하였다. 발화속도 측정은 전체 실험 문장에 대한 문자수를 낭독하는데 소요된 시간으로 나 눈 값으로 추출하였다.

실험에 적용한 음성 분석 요소들은 간 질환에 따른 음성 의 특징 변화를 추출하기 위해 다양한 음성 분석 실험에서 유의성이 도출되는 분석 요소만을 선정하였다. 제 3 포먼트 주파수 대역폭의 경우, 한글의 특징상 영어와 달리 자음만 을 끄집어서 발음을 시킬 수 없기 때문에 일반인이 발음하 기 쉬운 문장 단위로 실험을 행하였다. 제 3 포먼트는 '이'를 부딪히는 소리와 관련된 공명 주파수이고 이때 모음이 함께 연계되기 때문에 실험을 진행하는데 큰 문제가 없으며 포먼 트의 정확한 수치를 보자는 것이 아니고 포먼트 주파수 대 역폭의 변화를 측정하는 것이기 때문에 간 질환에 따른 음 성학적 유의성 분석에 적용하였다. 또한, Number of Voice Breaks는 실험 문장에서 단순히 보여지는 유성음과 무성음 의 개수를 의미하는 것이 아니라 실험 문장을 낭독하는 과 정에서 음성이 잠시라도 멈춘 구간을 의미한다. 최종적으로 다양한 음성 분석 요소를 적용한 실험을 통해 유의성이 도 출되는 3 포먼트 주파수 대역폭, Number of Voice Breaks 및 발화속도를 기반으로 연구를 진행하였다.

\section{3. 실험 결과 및 분석}

본 논문에서는 간 질환에 따른 음성의 변화를 공명강과 발성에 미치는 음성학적 분석 실험을 수행하였다. 이를 위해 한의학적 진단 이론에 근거하여 간과 음성의 연관성이 아음 에 해당하는 “ᄀ, 77 " 발음이라는 전제조건하에 "가까이 사는 가까끼는 코끼리와 같다.”라는 실험 문장을 녹음하여 제 3 포 먼트 주파수 대역폭, Number of Voice Breaks 및 발화 속도 를 분석하는 실험을 수행하였다. 논문에서 사용한 실험 환경 은 Microsoft Windows XP Professional을 운영체제로 사용 하였으며 음성 데이터 수집 장치로는 스테레오 고품질 녹음 모드인 STHQ 방식의 SONY ICD-SX67을 사용하였고 음성 신호의 비교 - 분석을 위해 사용한 음성 분석 도구는 Praat 5.0.23의 Third Formant Bandwidth Analysis, Voice Breaks Analysis 및 Voice Rates Analysis 요소를 사용하였다. 
아래 <표 4>는 남성 피실험자 집단을 대상으로 간 질환 으로 인해 입원한 환자들에 대한 간 질환 치료 전과 후의 제3포먼트 주파수 대역폭, Number of Voice Breaks 및 발 화 속도를 측정한 결과이다. 또한, <표 5>는 여성 피실험자 집단을 대상으로 간 질환으로 인해 입원한 환자들에 대한 간 질환 치료 전과 후의 제 3 포먼트 주파수 대역폭, Number of Voice Breaks 및 발화 속도를 측정한 결과이다.

실험 결과에서 나타나듯이 남성 피실험자 집단에서는 전 체 25명의 피실험자 중 $88.0 \%$ 에 해당하는 22 명이 제 3 포먼트 주파수 대역폭 분석 결과, 간 질환 치료 전보다 치료 후의 음성이 좁게 측정되는 변화를 나타냈으며 $96.0 \%$ 에 해당하는 24명이 Number of Voice Breaks 분석 결과, 간 질환 치료 전보다 치료 후의 음성이 적게 측정되는 변화를 나타냈다. 또한, $92.0 \%$ 에 해당하는 23 명이 발화속도 분석 결과, 간 질 환 치료 전보다 치료 후의 음성이 빠르게 측정되는 변화를 나타냈다.
여성 피실험자 집단에서도 동일한 결과가 측정되었는데 전체 15 명의 피실험자 중 $86.7 \%$ 에 해당하는 13 명이 제 3 포먼 트 주파수 대역폭 분석 결과, 간 질환 치료 전보다 치료 후 의 음성이 좁게 측정되는 변화를 나타냈으며 $93.3 \%$ 에 해당 하는 14명이 Number of Voice Breaks와 발화속도 분석 결 과, 간 질환 치료 전보다 치료 후의 음성이 적고 빠르게 측 정되는 변화를 나타냈다.

즉, 한의학적 진단 이론의 예로 심장은 혀, 신장은 귀와 연결이 되어 있다. 따라서 심장이 안 좋아지면 설음이 불명 료해지고 신장의 경우 귀에 이명 현상이 발생하며 수(水)기 운을 담당하는 기관이다보니 가라앉는 음성이 나오는 특징 이 있다. 이와 같은 관점에서 간은 '이'와 연계되어 있다. 따 라서 간이 안 좋아지면 잇소리 즉, 아음이 불명료해지며 잇 소리를 제대로 잘 내는지를 분석해 볼 수 있는 음성 분석 요소를 찾기 위해 여러 포먼트를 적용한 결과, 3 포먼트 주 파수 대역폭에서 실험 결과와 같이 유의성이 도출되었다.

〈표 4〉남성 피실험자 집단 실험 결과

\begin{tabular}{|c|c|c|c|c|c|c|}
\hline \multirow{2}{*}{ 구분 } & \multicolumn{2}{|c|}{ 3포먼트 주파수 대역폭 } & \multicolumn{2}{|c|}{ Number of Voice Breaks } & \multicolumn{2}{|c|}{ 발화속도 } \\
\hline & 치료 전 & 치료 후 & 치료 전 & 치료 후 & 치료 전 & 치료 후 \\
\hline LM-01 & 881.559 & 616.916 & 10 & 8 & 0.22 & 0.20 \\
\hline LM-02 & 351.262 & 159.139 & 11 & 8 & 0.19 & 0.17 \\
\hline LM-03 & 610.856 & 587.362 & 13 & 11 & 0.41 & 0.36 \\
\hline LM-04 & 630.857 & 318.873 & 11 & 10 & 0.37 & 0.31 \\
\hline LM-05 & 381.620 & 477.898 & 11 & 10 & 0.29 & 0.28 \\
\hline LM-06 & 1014.636 & 440.504 & 11 & 10 & 0.37 & 0.47 \\
\hline LM-07 & 1269.658 & 622.399 & 16 & 9 & 0.86 & 0.30 \\
\hline LM-08 & 680.677 & 84.502 & 9 & 6 & 0.33 & 0.14 \\
\hline LM-09 & 258.242 & 198.65 & 11 & 10 & 0.37 & 0.32 \\
\hline LM-10 & 530.907 & 199.381 & 7 & 6 & 0.18 & 0.17 \\
\hline LM-11 & 624.258 & 428.415 & 10 & 8 & 0.44 & 0.41 \\
\hline LM-12 & 394.401 & 336.480 & 11 & 10 & 0.38 & 0.34 \\
\hline LM-13 & 648.525 & 527.841 & 11 & 9 & 0.42 & 0.37 \\
\hline LM-14 & 457.652 & 521.482 & 10 & 8 & 0.28 & 0.27 \\
\hline LM-15 & 805.127 & 669.482 & 9 & 10 & 0.51 & 0.39 \\
\hline LM-16 & 668.640 & 642.841 & 11 & 10 & 0.46 & 0.43 \\
\hline LM-17 & 724.684 & 650.259 & 9 & 7 & 0.37 & 0.35 \\
\hline LM-18 & 482.659 & 295.438 & 10 & 8 & 0.27 & 0.24 \\
\hline LM-19 & 930.547 & 704.628 & 10 & 9 & 0.65 & 0.71 \\
\hline LM-20 & 428.625 & 368.750 & 11 & 8 & 0.33 & 0.32 \\
\hline LM-21 & 634.106 & 426.854 & 11 & 10 & 0.42 & 0.36 \\
\hline LM-22 & 673.820 & 694.520 & 8 & 6 & 0.28 & 0.25 \\
\hline LM-23 & 1025.624 & 753.269 & 10 & 8 & 0.72 & 0.49 \\
\hline LM-24 & 524.918 & 482.671 & 11 & 10 & 0.39 & 0.38 \\
\hline LM-25 & 614.538 & 467.295 & 9 & 7 & 0.36 & 0.31 \\
\hline
\end{tabular}


〈표 5〉여성 피실험자 집단 실험 결과

\begin{tabular}{c|c|c|c|c|c|c}
\hline \multirow{2}{*}{ 구분 } & \multicolumn{2}{|c|}{3 포먼트 주파수 대역폭 } & Number of Voice Breaks & \multicolumn{2}{|c}{ 발화속도 } \\
\cline { 2 - 7 } & 치료 전 & 치료 후 & 치료 전 & 치료 후 & 치료 전 & 치료 후 \\
\hline LF-01 & 101.848 & 183.746 & 14 & 9 & 0.28 & 0.26 \\
\hline LF-02 & 247.133 & 179.89 & 12 & 9 & 0.22 & 0.19 \\
\hline LF-03 & 246.894 & 180.419 & 11 & 9 & 0.19 & 0.17 \\
\hline LF-04 & 287.505 & 281.317 & 15 & 6 & 0.29 & 0.22 \\
\hline LF-05 & 206.028 & 144.363 & 8 & 9 & 0.26 & 0.20 \\
\hline LF-06 & 204.852 & 174.381 & 12 & 10 & 0.27 & 0.25 \\
\hline LF-07 & 224.925 & 189.420 & 14 & 11 & 0.32 & 0.29 \\
\hline LF-08 & 157.824 & 176.281 & 12 & 8 & 0.29 & 0.28 \\
\hline LF-09 & 238.415 & 176.547 & 14 & 9 & 0.26 & 0.23 \\
\hline LF-10 & 342.154 & 294.582 & 10 & 8 & 0.18 & 0.17 \\
\hline LF-11 & 241.348 & 204.617 & 11 & 8 & 0.38 & 0.32 \\
\hline LF-12 & 186.485 & 174.034 & 14 & 10 & 0.27 & 0.24 \\
\hline LF-13 & 224.895 & 196.548 & 10 & 7 & 0.24 & 0.22 \\
\hline LF-14 & 268.487 & 228.347 & 11 & 9 & 0.28 & 0.31 \\
\hline LF-15 & 315.627 & 296.410 & 13 & 9 & 0.34 & 0.28 \\
\hline
\end{tabular}

즉, 3 포먼트 주파수 대역폭이 작을수록 잇소리를 안정적으 로 내고 있다는 것으로 분석된다. 또한, Number of Voice Breaks와 발화속도의 경우는 다양한 음성 분석 요소를 적용 한 실험을 통해 새롭게 발견해 낸 간과 소리와의 관계라고 볼 수 있으며 결과적으로 간에 이상이 생기면 잇소리 즉, 아음이 불명료해진다는 한의학의 이론을 3 포먼트 주파수 대역폭, Number of Voice Breaks 및 발화속도라는 음성 분 석 기술로 입증할 수 있다.

실험 결과를 기반으로 피실험자 집단의 간 질환 치료 전 과 후 사이에 공명강과 발성의 상관성이 존재하는지에 대한 음성 분석학적 정보를 추출하여 간 질환이 공명강과 발성에 미치는 영향을 분석하였다. 실험 결과를 기반으로 간 질환 치료 전과 후의 제3포먼트 주파수 대역폭, Number of Voice Breaks 및 발화속도 변화량에 대한 통계적 유의성을 분석하 기 위한 실험 결과의 평균치 비교 분석을 수행하였다.

실험 결과의 상관성을 분석하기 위해 두 표본의 제3포먼 트 주파수 대역폭, Number of Voice Breaks 및 발화속도의 평균치 비교 방식을 도입하여 Paired T-Test 방식에 의한 통계 분석을 수행하였다. 즉, 동일 개체에 대한 두 표본평균 치의 비교를 통계적으로 분석하는 Paired T-Test 방식을 적용하여 실험 결과에 대한 통계적 유의성을 분석하였다 [10]. 아래 <표 6>에서 <표 8>은 남성 피실험자 집단의 간 질환 치료 전과 후의 음성에 대한 제 3 포먼트 주파수 대역폭, Number of Voice Breaks 및 발화속도에 대한 표본평균치 비교, 분석 결과를 나타낸 것이다. 또한, <표 9>에서<표 $11>$ 은 여성 피실험자 집단의 간 질환 치료 전과 후의 음성 에 대한 제3포먼트 주파수 대역폭, Number of Voice
Breaks 및 발화속도에 대한 표본평균치 비교, 분석 결과를 나타낸 것이다.

통계적 유의성 분석 결과를 통해 남성 피실험자 집단은 간 질환 치료 전과 후의 제3포먼트 주파수 대역폭, Number of Voice Breaks 및 발화속도의 유의확률이 각각 $0.000090366,0.000001008,0.019883106$ 으로 측정되었으며 여 성 피실험자 집단은 간 질환 치료 전과 후의 제 3 포먼트 주 파수 대역폭, Number of Voice Breaks 및 발화속도의 유의 확률이 각각 $0.015433144,0.000033912,0.000541354$ 로 측정되 어 실험에서 적용된 모든 음성 분석 파라메터에서 유의수준 0.05 보다 작게 추출되어 검정 통계량이 유의한 값을 보였음 을 알 수 있다.

〈표 6〉남성 피실험자 집단의 제3포먼트 주파수 대역폭 통계 분석 결과

\begin{tabular}{c|c|c}
\hline $\begin{array}{c}\text { 제3포먼트 주파수 } \\
\text { 대역폭 }\end{array}$ & 치료 전 & 치료 후 \\
\hline 평균 & 649.93592 & 467.03396 \\
\hline 분산 & 56243.34742 & 34600.46637 \\
\hline 피어슨 상관 계수 & \multicolumn{2}{|c}{0.599472702} \\
\hline $\mathrm{t}$ 통계량 & 4.694207928 \\
\hline $\mathrm{P}(\mathrm{T}<=\mathrm{t})$ 단측 검정 & 0.000045183 \\
\hline $\mathrm{t}$ 기각치 단측 검정 & 1.710882067 \\
\hline $\mathrm{P}(\mathrm{T}<=\mathrm{t})$ 양측 검정 & \multicolumn{2}{|c}{0.000090366} \\
\hline $\mathrm{t}$ 기각치 양측 검정 & 2.063898547 \\
\hline
\end{tabular}


〈표 7〉남성 피실험자 집단의 Number of Voice Breaks 통계 분석 결과

\begin{tabular}{c|c|c}
\hline $\begin{array}{c}\text { Number of Voice } \\
\text { Breaks }\end{array}$ & 치료 전 & 치료 후 \\
\hline 평균 & 10.44 & 8.64 \\
\hline 분산 & 2.84 & 2.156666667 \\
\hline 피어슨 상관 계수 & \multicolumn{2}{|c}{0.622257354} \\
\hline $\mathrm{t}$ 통계량 & \multicolumn{2}{|c}{6.500836067} \\
\hline $\mathrm{P}(\mathrm{T}<=\mathrm{t})$ 단측 검정 & \multicolumn{2}{|c}{0.000000504} \\
\hline $\mathrm{t}$ 기각치 단측 검정 & \multicolumn{2}{|c}{1.710882067} \\
\hline $\mathrm{P}(\mathrm{T}<=\mathrm{t})$ 양측 검정 & \multicolumn{2}{|c}{0.000001008} \\
\hline $\mathrm{t}$ 기각치 양측 검정 & \multicolumn{2}{|c}{2.063898547} \\
\hline
\end{tabular}

〈표 8〉남성 피실험자 집단의 발화속도 통계 분석 결과

\begin{tabular}{c|c|c}
\hline 발화속도 & 치료 전 & 치료 후 \\
\hline 평균 & 0.3948 & 0.3336 \\
\hline 분산 & 0.024676 & 0.014265667 \\
\hline 피어슨 상관 계수 & \multicolumn{2}{|c}{0.636848351} \\
\hline $\mathrm{t}$ 통계량 & 2.494795504 \\
\hline $\mathrm{P}(\mathrm{T}<=\mathrm{t})$ 단측 검정 & 0.009941553 \\
\hline $\mathrm{t}$ 기각치 단측 검정 & 1.710882067 \\
\hline $\mathrm{P}(\mathrm{T}<=\mathrm{t})$ 양측 검정 & \multicolumn{2}{|c}{0.019883106} \\
\hline $\mathrm{t}$ 기각치 양측 검정 & 2.063898547 \\
\hline
\end{tabular}

〈표 9〉여성 피실험자 집단의 제3포먼트 주파수 대역폭 통계 분석 결과

\begin{tabular}{c|c|c}
\hline $\begin{array}{c}\text { 제3포먼트 주파수 } \\
\text { 대역폭 }\end{array}$ & 치료 전 & 치료 후 \\
\hline 평균 & 232.9613333 & 205.3934667 \\
\hline 분산 & 3580.737965 & 2282.583808 \\
\hline 피어슨 상관 계수 & \multicolumn{2}{|c}{0.763140363} \\
\hline $\mathrm{t}$ 통계량 & 2.75694193 \\
\hline $\mathrm{P}(\mathrm{T}<=\mathrm{t})$ 단측 검정 & 0.007716572 \\
\hline $\mathrm{t}$ 기각치 단측 검정 & 1.761310115 \\
\hline $\mathrm{P}(\mathrm{T}<=\mathrm{t})$ 양측 검정 & 0.015433144 \\
\hline $\mathrm{t}$ 기각치 양측 검정 & 2.144786681 \\
\hline
\end{tabular}

〈표 10〉여성 피실험자 집단의 Number of Voice Breaks 통계 분석 결과

\begin{tabular}{c|c|c}
\hline $\begin{array}{c}\text { Number of Voice } \\
\text { Breaks }\end{array}$ & 치료 전 & 치료 후 \\
\hline 평균 & 12.06666667 & 8.733333333 \\
\hline 분산 & 3.780952381 & 1.495238095 \\
\hline 피어슨 상관 계수 & \multicolumn{2}{|c}{0.128175464} \\
\hline $\mathrm{t}$ 통계량 & 5.976143047 \\
\hline $\mathrm{P}(\mathrm{T}<=\mathrm{t})$ 단측 검정 & \multicolumn{2}{|c}{0.000016956} \\
\hline $\mathrm{t}$ 기각치 단측 검정 & 1.761310115 \\
\hline $\mathrm{P}(\mathrm{T}<=\mathrm{t})$ 양측 검정 & \multicolumn{2}{|c}{0.000033912} \\
\hline $\mathrm{t}$ 기각치 양측 검정 & 2.144786681 \\
\hline
\end{tabular}

〈표 11〉여성 피실험자 집단의 발화속도 통계 분석 결과

\begin{tabular}{c|c|c}
\hline 발화속도 & 치료 전 & 치료 후 \\
\hline 평균 & 0.271333333 & 0.242 \\
\hline 분산 & 0.002755238 & 0.002302857 \\
\hline 피어슨 상관 계수 & 0.875094229 \\
\hline $\mathrm{t}$ 통계량 & 4.457686366 \\
\hline $\mathrm{P}(\mathrm{T}<=\mathrm{t})$ 단측 검정 & 0.000270677 \\
\hline $\mathrm{t}$ 기각치 단측 검정 & 1.761310115 \\
\hline $\mathrm{P}(\mathrm{T}<=\mathrm{t})$ 양측 검정 & 0.000541354 \\
\hline $\mathrm{t}$ 기각치 양측 검정 & 2.144786681 \\
\hline
\end{tabular}

\section{4. 결 론}

현대 사회에서 의료 서비스 분야는 건강한 삶을 향상시키 기 위한 필수조건으로 다양화되어 실생활에 활용되고 있다. 특히, 의료 IT 융합 분야에 대한 정부의 국가 전략 정책이 치료 분야에서 건강관리 및 유지 산업으로 방향이 전환되면 서 예방 및 보건 차원의 의료 산업에 많은 연구가 진행되고 있다. 특히, IT의 네트워크화, 지능화, 내재화의 특성을 통해 기존 기술 및 산업간 융합의 원천기술화 시키는 IT 융합 산 업이 경쟁력 우위 확보 및 신성장 동력화로 추진되면서 IT 기술과 의료 분야간의 융복합화가 급속히 촉진되고 있다.

따라서 본 논문에서는 간질환이 음성에 미치는 영향을 연 구하기 위해 간 질환자를 대상으로 치료 전과 후의 공명강 과 발성의 변화를 측정하여 비교, 분석하는 연구를 수행하 였다. 이를 위해 간 질환을 않고 있는 환자를 대상으로 치 료 전과 후의 음성을 수집하여 제 3 포먼트 주파수 대역폭, Number of Voice Breaks 및 발화속도의 변화를 측정하여 상호간의 비교, 분석을 수행하였다. 실험 결과에서 알 수 있 듯이 간 질환을 않고 있는 피실험자 집단에서 치료 전보다 후의 제 3 포먼트 주파수 대역폭은 남성 집단의 $88.0 \%$, 여성 집단의 $86.7 \%$ 가 각각 감소하였으며 Number of Voice Breaks는 남성 집단의 $96.0 \%$, 여성 집단의 $93.3 \%$ 가 각각 감 소하는 결과를 나타냈다. 또한, 발화속도는 남성 집단의 $92.0 \%$, 여성 집단의 $93.3 \%$ 가 각각 빠르게 측정되는 결과를 나타냈다. 이와 같은 결과는 간과 엄쏘리인 아음과의 한의 학적 관계 기반의 이론을 제3포먼트 주파수 대역폭, Number of Voice Breaks 및 발화속도를 적용한 연구 결과 로 결론적으로 간 질환에 의해 공명강과 발성에 영향을 미 치는 것으로 분석된다.

\section{참 고 문 헌}

[1] 대한소화기학회, 간염, 군자출판사, 2005.

[2] 보건복지부, 보건복지통계연보, 2009

[3] 이미연, "종합검진 초음파에서 나타난 간질환과 건강관련 요인 분석”, 한국방사선기술연구회지, 2009.

[4] 고바야시 산고, 간장 심장편, 집문당, 2002. 
[5] 김동우, 한방으로 다스리는 간, 홍신문화사, 2006.

[6] 지선하, 한국인 간질환의 변천, 한국간협회, 1998.

[7] 태웅건강연구회, 간장 클리닉, 태웅출판사, 2000.

[8] 김시천, “감각이란 무엇인가-동양철학적 접근", 한국철학사상연 구회 제18권 제 3 호 pp.491-520, 2007.

[9] 조성문, “현대 국어의 모음 체계에 대한 음향음성학적인 연구”, 한국언어문화학회 제 24 집 pp.427-441, 2003.

[10] 동의과학연구소, 동의보감 내경편, 휴머니스트, 2002.

[11] 양병곤, 프라트를 이용한 음성분석의 이론과 실제, 만수출판사, 2003.

[12] 고도흥, 정옥란 외 공편, 음성 및 언어 분석기기 활용법, 한국문 화사, 2001.

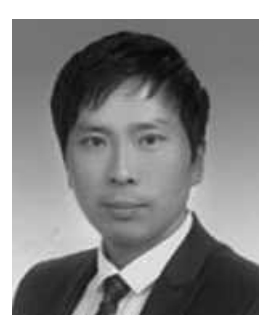

\section{김 봉 현}

e-mail :kimbh@cpu.ac.kr

2000년 한밭대학교 전자계산학과(공학사)

2002년 한밭대학교 전자계산학과(공학석사)

2009년 한밭대학교 컴퓨터공학과(공학박사)

2002년 현 재 한밭대학교 컴퓨터공학과

$$
\text { 외래강사 }
$$

2005년 현 재 충북도립대학교 전자정보계열 외래강사

2009년 한국정보처리학회 논문대상 수상

2011년 한국정보처리학회 최우수논문상 수상

관심분야: 생체신호분석, 음성처리

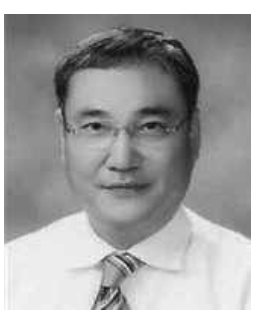

조 동 욱

e-mail : ducho@cpu.ac.kr

1983년 한양대학교 전자공학과(공학사)

1985년 한양대학교 전자공학과(공학석사)

1989년 한양대학교 전자통신공학과

(공학박사)

1991년 2000년 서원대학교 정보통신공학과 부교수

1999년 Oregon State University 교환교수

2000년 현 재 충북도립대학교 전자정보계열 교수 2009년 현 재 한국정보처리학회 부회장

2007년 기술혁신대전 대통령 표창 수상

2008년 한국정보처리학회 학술대상 수상

2009년 한국산학기술학회 학술대상 수상

2010년 충청북도 도지사 표창 수상

2011년 한국정보처리학회 최우수논문상 수상

2011년 기술혁신대전 교육과학기술부장관 표창 수상

관심분야: 생체신호분석, 영상처리 